\title{
Voicing Rivers
}

Sandra Wooltorton ${ }^{1}$, Laurie Guimond ${ }^{1}$, Peter Reason ${ }^{1}$, Anne Poelina $^{1}$, and Pierre Horwitz ${ }^{1}$

${ }^{1}$ Affiliation not available

January 12, 2022

\begin{abstract}
Welcome to this Special Issue of River Research and Applications, entitled Voicing Rivers. As an editorial group, it has been a great privilege to read and consider responses to our call for contributions and share with readers, authors and reviewers involved in this journey. We invited proposals for articles and creative work to focus on stories of, by, from and for rivers, from a variety of perspectives. This Special Issue has been a collaborative project involving nearly 20 rivers and over 50 people. We thank contributors, reviewers and the River Research and Applications journal editorial and production team.
\end{abstract}

\section{Hosted file}

Voicing Rivers Preprint.pdf available at https://authorea.com/users/426634/articles/552542voicing-rivers 